\title{
BUSINESS SCHOOL LEADERSHIP FOR A SUSTAINABLE, FLOURISHING, AND REGENERATING WORLD
}

\author{
JAMES A. F. STONER \\ Gabelli School of Business \\ Fordham University, New York, New York, U.S.A. \\ stoner@fordham.edu
}

The business schools of the world have an exceptional opportunity to contribute to transformations in both who we are as people living on this planet and how we produce, distribute, and consume the goods and services that meet our needs. They can inspire and mobilize a global movement to bring about these transformations that the world sorely needs, particularly by communicating the opportunities they have and by working with a common purpose in collaboration with many other individuals and organizations who seek the same end: the flourishing of all species on this planet "forever."

The articles in this issue of the Journal suggest as much, that business schools and universities are making such contributions in many ways. This editorial thus proposes that the world's business schools can continue and expand their contributions, namely by committing to and starting the process of transforming what they currently teach and research away from the creation of "business as usual" (BAU) mindsets and practices that this planet has shown it can no longer support, and by replacing those with ones that are aligned not with the myths and realities of the $19^{\text {th }}$ and $20^{\text {th }}$ centuries but with the realities of the $21^{\text {st }}$. Every faculty member, dean, university president, and, perhaps, alumnus, administrator, or student can start bringing this movement into being today.

\section{SEVEN ACUPUNCTURE POINTS, ONE NEEDLE}

Almost a decade ago, Otto Scharmer described-and has done so again many times since-“seven acupuncture points" (Scharmer, 2014), sometimes eight, that 
offer the opportunity to transform our-then and even more now-broken global ecosystem (e.g., Scharmer, 2010, 2014, 2017). Those points are more than worthy of being repeated today. The original seven are:

1. Coordination mechanisms: Upgrade the economic operating system from one driven by competition and special-interest-group-led legislation ("ego-system awareness") to one that operates from shared seeing and common will (driven by an intentional "eco-system awareness").

2. Nature: Design all production and consumption cycles completely earth-to-earth (without the need for landfills and in co-evolution with the natural ecosystem).

3. Labour: Create economic human rights (such as basic income, access to health, education, entrepreneurial opportunity) in order to enable all people to actualize their full creativity for shared wealth generation and social well-being.

4. Capital: Redesign and redirect money and capital flows to serve all sectors of the economic system (and develop commons-based property rights in support of it).

5. Technology: Build communities of creation to generate breakthrough technologies in areas that matter most to societal needs and aspirations.

6. Leadership: Reinvent leadership learning to facilitate "learning from the emerging future" rather than reproducing the patterns of the past.

7. Public Awareness and Conversation: Create infrastructure innovations that allow all citizens to become aware of their real power in co-creating the intentional ecosystem economy and in deepening our democracy. (Scharmer, 2010)

A thoughtful review of these points, seen through the lenses of what business education and research could become, suggests that every one of them can be moved forward by business school leadership. For some points the opportunity is obvious, for others it is more subtle; yet all are opportunities for business schools to be the needle that leads and inspires many others to bring about systemic change and healing in every one of these areas as articulated by Scharmer. 


\section{TRANSFORMING BUSINESS EDUCATION AND RESEARCH}

While there are some notable and important exceptions, global business education as a whole does not currently contribute to seizing the opportunities identified by Scharmer and many others. In fact, much of business education throughout the world currently does the exact opposite, providing to a large extent the mindsets and tools that support business practices that have been labeled "business as usual" (BAU).

This situation is not surprising. Business schools often see it as their most obvious obligation to serve two sets of customers: their students and the potential employers of their graduates. And both are served by giving business what it most consistently calls for: graduates and interns who can contribute to what businesses seek to do and how they seek to do it-business as usual. Hence, given that the great bulk of jobs are currently in business as usual- "that's where the jobs are!"-this emphasis appears, at least on the surface, to be eminently sensible.

There is, unfortunately, "one little problem" in this cheery scenario: business as usual is destroying the capacity of the planet to support our own and other species. And every year it appears that this destruction is occurring at a rate faster than what was estimated the year before.

Fortunately, there are jobs related to sustainability, flourishing, and regeneration in many businesses and other organizations. These jobs are growing, and many businesses indicate a desire to find graduates who can bring to the table the advantages of the "business case for sustainability" — making more money by doing less harm. Many business schools have been responding to these calls-some for more than a decade-and are producing new types of graduates, ones educated in the need to create a sustainable world and armed with the tools and mindsets to contribute to the creation of such a world-or at least to do less harm as they increase company profits. This training is valuable and important; it should and must continue. Doing less harm, no matter what the motivation, is surely better than doing more of it. Yet doing so, however, does not go nearly far enough toward seizing the opportunities that Scharmer describes. 


\section{BEYOND “EMBEDDING SUSTAINABLITY” IN BUSINESS COURSES}

Significant progress has been made in many business schools when it comes to building sustainability knowledge and skills into the curriculum, although these actions frequently take the form of upper level, optional, and disciplinefocused courses that are taken by a minority of students. Classes with titles such as Sustainable Marketing, Accounting for a Sustainable World, Sustainable Supply Chain Management, and even Sustainable Finance exist; some have been taught for many years. A large number of schools offer minors or even majors in sustainability, while for a few others the program for all students is grounded in sustainability (e.g., Bard College's Sustainability MBA and the University of Vermont's Sustainable Innovation Curriculum).

All these initiatives are valuable. They can offer important ideas, guidance, and resources for schools that want to go well beyond simply adding aspects of sustainability to curricula that are often grounded in well-established and ever so comfortable "business as usual" ways of teaching and managing.

\section{ALIGNING REQUIRED CORE COURSES IN THE BUSINESS CURRICULUM WITH THE NEED FOR A SUSTAINABLE WORLD}

For schools and faculty leaders who want to be among the early ones in seizing the opportunities described by Scharmer's seven acupuncture points or one of the other promising ways of starting the transformation of business education and practice, a fruitful approach may be to start aligning all required first level core courses in each functional area of the business curriculum with the need for creating a sustainable, flourishing, and regenerating world.

It might be tempting to think that upper level and advanced courses in sustainability topics are doing "rework" in the quality management sense—doing a task a second time over to correct errors made earlier in the process. Upper level courses, however, do not correct the errors in mindset and actions that core courses teach. They simply continue doing harm but on a reduced level. They continue the very basis of the core courses-to do only those things that can be shown to add to current profits and to keep on doing things even if they have the potential to harm the future as long as they are profitable today. They do not ask the much more basic $21^{\text {st }}$ century question, that is, "how can we contribute the most to the well-being 
of present and future generations, and in ways that generate sufficient economic surplus to enable us to continue doing so in the present and hopefully expand our ability to make greater contributions in the future?"

For faculty members, focusing on aligning core courses with the need for a sustainable world in particular is exciting in that it is intellectually very challenging to do so; a rich source of ideas for new, exciting, and very publishable research projects; and fully consistent in many ways with the obligations and "academic freedoms" of faculty members. How can one be opposed to aligning what we teach and research with the realities of the $21^{\text {st }}$ century?

\section{THE RIGHT PEOPLE IN THE RIGHT PLACE AT THE RIGHT TIME}

We do need to find ways to become the kinds of people who can flourish on this planet in a manner that heals it, and we need to find new, planet-friendly means to produce, distribute, and consume the goods and services we all need. None of us knows for sure how to do this, and so we need a great many initiatives pursued with much creativity and boldness to start figuring out how to do so. There are many, many business schools throughout the world; together they have the intellectual resources, sheer numbers of faculty members (and students and alumni and administrators), access to financial resources, and moral and spiritual obligations to make figuring out how to undertake the great adventure of our lifetime their highest priority. Doing so, in many ways, is simply a matter of committing to start this adventure and to taking the first steps ... and perhaps to remember, along the way, a quotation frequently attributed to Johann Wolfgang von Goethe but given to us, apparently, by William Hutchinson Murray:

Until one is committed, there is hesitancy, the chance to draw back, always ineffectiveness. Concerning all acts of initiative (and creation), there is one elementary truth, the ignorance of which kills countless ideas and splendid plans: that the moment one definitely commits oneself, then Providence moves too. All sorts of things occur to help one that would never otherwise have occurred. A whole stream of events issues from the decision, raising in one's favour all manner of unforeseen incidents and meetings and material assistance, which no man could have dreamt would have come his way.

[Murray goes on to say:] I have learned a deep respect for one of Goethe's couplets: Whatever you can do, or dream you can, begin it. Boldness has genius, power, and magic in it! (Murray, n.d.) 


\section{THE GLOBAL AND THE LOCAL IN THE BUSINESS CURRICULUM}

As we look at the possibilities of transforming business school teaching and research, we need to understand the context of each particular society, e.g., the state of its economy, its culture, and its people's worldviews. People at the bottom of the pyramid in developing countries, for example, often prioritize livelihood over choosing green options that can help respond to climate change, even if they are the ones who are usually the most severely impacted by such changes. Experiencing the face of poverty and the environmental degradation in vulnerable areas of the world can thus help students in both the most privileged and most vulnerable parts of the globe to contribute to effective solutions that respect their own local contexts. It is important, therefore, to design business curricula and research that can help students become more responsive to the integral ecology in their context and find sustainable solutions in that context.

This perspective is especially clear perhaps in this issue of the Journal. Although it was not the original intention, all the papers in this issue reflect voices of the Global South in some way or other. Four articles come from professors in Asia or Southeast Asia; the other, from researchers and professors at Seattle University, speaks directly to issues and concerns of the Global South.

This issue of the Journal begins with an exploration of the need to take a holistic perspective in our pursuit of efforts to create, as stressed in the Journal's 2013 definition of global sustainability, "a world that works for everyone with no one left out." In this first and invited piece, we hear voices from the research team of Pedro Walpole, S.J., the Director of Research at the Institute of Environmental Science for Social Change in the Philippines and Coordinator of Reconciliation with Creation for the Jesuit Conference Asia Pacific. The research team's work echoes the call of Laudato Si' (Francis, 2015) to take a holistic and integral perspective in addressing the challenges of human and social conditions and in the efforts to alleviate these within marginal areas. In this paper, those conditions are in the uplands of Northern and Central Mindanao and are representative of similar circumstances throughout the world.

As our society and the world we live in teeter on the precipice of irreversible climate change, J. Andres Ignacio describes how we are called to take serious stock 
of the future that awaits us, a future that will affect not only our way of life but also the life systems of all things living on our planet. He argues that globalization has unfortunately become the engine that allows neoliberal-driven actions to exploit both our limited natural resources and the vulnerable sectors of local societies and communities. It has successfully fragmented and effectively reduced the rich diversity of both our resources and our cultures under the guise of "development" while we, in turn, have applied inappropriate metrics centered on quantity over quality to assess wellbeing and progress. He illustrates such situations by writing about upland corn farmers in Northern Mindanao, describing the dynamics of a corporate-driven economic model that depletes resources and exploits communities that have depended on the richness of the land for centuries.

Relationships with the land and with one another have thus been broken, resulting in fragmentation of the land and of society. Yet Ignacio says that we are now called to rebuild these relationships so as to restore the natural systems that can sustain our society for generations to come. We are challenged to pursue an economic model that is mindful of integral ecology, one anchored on care and respect for one another and for the land that sustains us.

In the second article, Rubiná Mahsud's and Jessica Imanaka's research on Global Collaborative Advantage (GCA) follows a decolonizing perspective within the field of business ethics and offers a strong attempt at incorporating diverse sources of wisdom from the Global South. GCA strives to bring the world's wisdom traditions together, drawing from a variety of global perspectives on humanity, society, and economics to broaden the possibilities for ethical, meaningful, and generative exchange in global markets, and, in doing so, seeks to de-center perspectives that originate from the Global North. It takes a macro level approach to integrate worldviews and yet allows for the translation of the derived and aggregated information to be applied at the meso and micro levels of business.

GCA is ultimately a call for scholars to reconsider the relevance of what we write and produce. It offers a way of bolstering collaboration and open-mindedness through an approach that de-centers the loudest voice of the North and centers the unheard voices of the South, thereby vocalizing their own wisdoms and traditions. Indeed, management for global sustainability requires constant attention to the most vulnerable stakeholders and the global problems that continue to beset them. 
The final three papers in this issue all focus on the contribution that schools and educational initiatives can make toward a more sustainable world. In the first of these, Anna Mendiola of Ateneo de Manila University looks at how students can influence their schools as the latter transition toward more sustainabilitydriven teaching and action. She reports how her daughter, who is a few years out of college, sometimes talks to her about how badly she wants to help the environment. Mendiola confesses to feeling helpless, however, unsure whether the small actions she takes really do make a difference. She notes that there may be many other students like her daughter who want to contribute their share, and emphasizes that schools can be instrumental in harnessing their collective power to make a difference in efforts toward sustainability.

Mendiola stresses that educational institutions can be powerful forces for moving the youth toward more sustainable lifestyles. Indeed, schools can be strong advocates for sustainability and significant catalysts for change. They can engage students and others, utilizing their energies to satisfy their desire to make a difference in the world. She sees how schools can establish momentum toward sustainability, creating a "spark" where everyone works with each other to come up with sustainability initiatives that are practical and viable. In doing so, schools can help students become lifetime advocates for a sustainable world.

The last two education-focused contributions in this issue also come from Asian countries faced with challenges of overpopulation, natural hazards, environmental damage, and the need to alleviate the suffering of those living in poverty.

The fourth paper of this issue describes the experiments and experiences at Mar Athanasios College for Advanced Studies (MACFAST) in Tiruvalla, Kerala, India as its community developed creative approaches toward becoming a sustainable campus. Fr. Abraham Mulamoottil, for instance, talks about how the school converted the problem of waste management into a resource for renewable energy (biogas). The school also extended its sustainability initiatives to the town of Tiruvalla, leading to the latter's recognition as a "clean and green" community, and founded and managed the first campus-based community radio station in the country, a station that became one of the main sources of income for the school and a way for the community to engage with it. 
The innovations at MACFAST have given the school a reputation for setting trends in the ways it approaches education. Going beyond the triple-bottom line of people, profit, and planet, it has added two more elements that are crucial for sustaining its innovations: passion and purpose. These involve getting students to have passion for study and be committed to self-development in the process and developing competent professionals with a purpose in life founded on spirituality.

Hailing from Southeast Asia, the final paper reports how Ateneo de Manila University in the Philippines also searched for innovative approaches to integrating sustainability into both its formal and informal structures. The school's members learned the key importance of stakeholder engagement early in their journey, particularly because it addresses two things. First, stakeholder concerns, ideas, and suggestions are heard and taken into consideration in planning and implementation. This listening gives stakeholders a voice and empowers them to work productively with the university. Second, stakeholder engagement is recognized as more effective than top-down, command-and-control approaches. Rather than being just "clients" who must be satisfied with the university's services, stakeholders become true partners in sustainability endeavors. Indeed, building "sustainability literacy" is another key, allowing stakeholders to understand the rationale underlying sustainability rules and guidelines and influence instead of just following them.

Other enablers of campus sustainability, including administrative support and strong leadership, were crucial in the success and continuation of these initiatives. The ultimate goal has been to arrive at an integrated sustainability, one that is not separate from existing policies and operations. Sustainability at Ateneo de Manila, as in many other institutions, is not intended to be a separate role or duty of stakeholders but rather a lens through which priorities and choices are viewed.

The urban biodiversity supported by the sustainability practices of education institutions like those featured here as well as of many other organizations and individuals is the inspiration behind the cover of this issue. It features a photo of a collared kingfisher (Todiramphus chloris) as taken by wildlife enthusiast Adrian M. Constantino, a symbol of how wildlife learns to thrive in urban settings. 


\section{REFERENCES}

Francis. 2015. Laudato si': On care for our common home. Vatican City: Libreria Editrice Vaticana.

Murray, W. H. n.d. William Hutchison Murray > Quotes > Quotable Quote. Goodreads. com. Available at https://www.goodreads.com/quotes/128689-until-one-iscommitted-there-is-hesitancy-the-chance-to (accessed December 10, 2019).

Scharmer, O. 2010. Seven acupuncture points for shifting capitalism to create a regenerative ecosystem economy. Oxford Leadership Journal, 1(3): 1-21. Available at https://www.ottoscharmer.com/sites/default/files/2010_Oxford_ SevenAcupuncturePoints.pdf (accessed December 10, 2019).

Scharmer, O. 2014. Eight acupuncture points for transforming capitalism. Huffpost, June 15. Available at https://www.huffpost.com/entry/eight-acupuncturepoints_b_5497657 (accessed December 10, 2019).

Scharmer, O. 2017. Transforming capitalism: 7 acupuncture points. Huffpost, April 1. Available at https://www.huffpost.com/entry/transformingcapitalism-seven-acupuncture-points_b_58e006cce4b03c2b30f6a6fa (accessed December 10, 2019). 